\title{
Teaching career's attraction and rejection factors: analysis of students and graduates perceptions in teacher education programs
}

Candido Alberto Gomes a

Janete Palazzo ${ }^{\text {b }}$

\section{Abstract}

This article presents part of the results of a research project aimed at analyzing factors of attraction and rejection associated to a teaching career as perceived by a cohort of undergraduate, finalist and graduate students of the teaching degree courses in Pedagogy and Mathematics of a private higher education institution in the Federal District. This project administered questionnaires and conducted focal group sessions and individual interviews. Thematic Analysis of Content was used for data analysis. The results show that some of the factors of attraction associated to a teaching career are those intrinsic to the profession (emotional gratification, reciprocal learning), while the factors of rejection are mostly extrinsic, such as financial rewards, social devaluation, work overload, violence in schools, teacher malaise and others. The paper concludes that, in spite of offering low salaries, teaching is an attractive career for candidates socially, economically and culturally less well off.

Keywords: Higher education. Teaching career. Career choice. Teacher education.

\section{Introduction}

Choosing a career marks a determinant moment in the life of any young person. The process of defining a profession and entering into the world of work depends on a series of intrinsic and extrinsic factors that relate to one another in different ways. Several authors have underscored that people's professional destinies do not only depend on their personal characteristics but also on the historical, social,

\footnotetext{
a Universidade Católica de Brasília. Brasília, Distrito Federal, Brasil.

b Universidade Católica de Brasília. Brasília, Distrito Federal, Brasil. 
political economic, family and other contexts they find themselves in (GATTI, 2009; RAMOS; LIMA, 1996; SOARES, 2002; VALLE, 2006). Ferreira, Nascimento and Fontaine (2009) state that the construction of vocational development is a social process that takes place in the interaction of the individual with himself, with others and with her/is social environment, depending on opportunities that may appear in the life of the individual. In the context of choosing a teaching career, Valle (2006) proposes two hypotheses for its occurrence: a) as the result of a conscious or unconscious decision made during higher secondary education, or before, due to the attraction that a teaching career effectively exercises on the student; or b) as a result of the impossibility of the student entering some other career for which he really has a vocation.

There are data showing that the numbers of students concluding teaching degree courses, especially in the fields of Chemistry, Physics, Mathematics and Biology are insufficient to meet the needs of the education systems (BECA, 2007; RUIZ; RAMOS; HINGEL, 2007), thereby showing that teaching has attracted too few young people in Brazil. That fact may make renovation difficult and lead to a shortage of professionals in Brazil in the not too distant future. Thus, the question arises: what are the factors of attraction and rejection associated to a teaching career?

The classical sociological research carried out by Lortie (2002) in five cities in the greater Boston metropolitan area identified the main factors of attraction of teaching in that particular spatial and temporal context. The author classified the results around five themes: 1) interpersonal relations; 2) teaching as "priesthood", a giving of oneself; 3) continuity; 4) material benefits; 5) compatibility of time.

The first theme was the most mentioned by the interviewees. "A taste for working with people" was the factor of attraction of the career. Indeed, teaching is one of the professions that offer constant contact with younger people. According to that author, while it is true that other professions like pediatrics and social assistance also work with children, in the teaching career contact is not restricted to sick or socially disadvantaged children. The second factor concerns the aspect of priesthood or a calling, giving of oneself. Many of the survey respondents cited this humanitarian and assistance-orientated aspect of the profession as being one of its attractions. The third theme includes those that quite simply like school and want to work in the field of education and others that like certain school-activities which would be hard for them to engage in outside of the school 
environment. The fourth aspect concerns material benefits (salary, prestige and employment security).

In turn, Rabelo (2010a; 2010b) investigated the reason for their choice of teaching as a career among male teachers working in the early schooling years of basic education in Aveiro, Portugal and in Rio de Janeiro and found that intrinsic factors (liking the profession and being fond of children) were the most relevant. Extrinsic factors like employability, profitability, the need for a job, and lack of opportunities were also mentioned. Souza (2010) found that most of the teaching degree undergraduates in his study had chosen the course because they wanted to become teachers. Liking the profession was also cited as a motive for the teachers to remain in it (GIESTA, 2008). The study of samples of students drawn from three different generations studying in the first and second semesters of a public teacher education school in Mexico City, conducted by Garduño and Sandoval (2006), showed that almost half those interviewed had chosen the profession for extrinsic reasons.

According to Valle (2006), the low level of attraction associated to a teaching career is connected to the following factors 1) uncertainty regarding the future of the profession; 2) poor salaries; 3 ) limited possibilities for personal ascension; and 4) precarious working conditions. In the view of Diniz-Pereira (2011), the crises that have affected teaching undergraduate programs are related to students' difficult experiences with their own upkeep during the course, the expectation of a poor salary level for the profession and the decline of teaching's social prestige. Based on bibliographic-documental research, Barbosa $(2011 ; 2012)$ concluded that the salary is one of the main factors responsible for the increasing precariousness of teaching work.

In an investigation of perceptions of attractive aspects of the teaching profession conducted among students in higher secondary education, Lima (2010) and Tartuce, Nunes and Almeida (2010) concluded that the main aspects discouraging students from entering the profession are linked to social and economic questions like poor pay, bad working conditions and the profession's lack of social recognition. Indeed, only $2 \%$ of students in higher secondary education had any intention of becoming teachers (TARTUCE; NUNES; ALMEIDA, 2010).

Gatti and Barreto (2009) argue that the unattractive salaries and career plans that have no structures to recompense, stimulate or motivate teachers in their activity interfere in the career choices of youngsters and impair the social valuation of 
the teaching profession. Fröhlich's (2013) research showed that if there were an increase of $1 \%$ in teachers' average salary as compared to other professionals in the municipality, the probability of the teaching degree courses being selected would increase by 8 to $20 \%$. However, it must be underscored that valuing the educators and their profession is not related to the salary alone but to various other factors such as social prestige and the recognition of their role as conflict mediators in the light of society's social, cultural and economic difficulties (PIMENTEL, PALAZZO, OLIVEIRA, 2009).

The unattractiveness of the teaching profession in Brazil has been confirmed by a series of research studies and in the practice of administrators. The lack of teachers makes itself felt in certain study subjects and certain regions and apparently the situation is currently getting worse. For those very reasons, as part of a study of this phenomenon (PALAZZO, 2015) begun in 2011, the present article sets out to analyze the factors of attraction and rejection associated to the teaching career.

\section{Method}

This exploratory research takes the form of a case study. Thus, the intentional sample was determined by the criteria that it should be a private institution and therefore have lower candidate/vacancy ratio than the public ones. A college with around 4,000 students enrolled, it was in the average degree of selectivity among the private ones. Its location was in an administrative region with an average family income close to the average family income for the Federal District as a whole (GOVERNO DE BRASÍLIA, 2012).

To generate and gather data, the study administered questionnaires and conducted focal group sessions and individual interviews. The questionnaires were administered live to undergraduate beginners and finalists. The return was $65.6 \%$ for beginners in the Pedagogy course and $78.3 \%$ of those in the Mathematics course; and among the finalists it was $67.4 \%$ from those in the Pedagogy course and $100 \%$ from those concluding their Mathematics course. In the case of university graduates, the questionnaires were administered by e-mail but the response rate was unsatisfactory ( $16.8 \%$ for Pedagogy and $23.4 \%$ for Math graduates). It was therefore decided to hold interviews by phone in order to complete at least $33.3 \%$ of the sample.

Each candidate was attributed an identification code of three letters representing respectively, his condition in the course (B for beginners, $F$ for finalists and $G$ for graduates), the course itself ( $\mathrm{P}$ for pedagogy, $\mathrm{M}$ for Mathematics) and gender 
( $\mathrm{F}$ for female and $\mathrm{M}$ for male) and after that came a number from one to 689. Thus, a code such as GPM-35 would represent participant number 35 who was a graduate $(\mathrm{G})$ of the Pedagogy course $(\mathrm{P})$ and a male $(\mathrm{M})$.

\subsection{Participants}

Research focused on groups made up of students and graduates in different situations: a) beginners in the Mathematics and Pedagogy courses who entered in the second semester of 2010 and the first semester of 2011; b) students concluding the same two courses in the first semester of 2012; and c) students that had graduated and left in any one of the five semesters from the 2 nd semester of 2010 to the 2 nd semester of 2012. Table 1 shows the numbers of students, by course and by condition in the course (undergraduate beginner, undergraduate finalist or graduate).

The answers to the questionnaires defined the social-economic-cultural profile of the participants. Table 2 is a synthesis of the predominant features of each group. The results show that survey participants were students from low-income families with very little knowledge of foreign languages, not frequent readers of books or newspapers and with only a timid presence in diversified cultural activities, these last usually being limited to the movies. Most of them had a higher schooling level than their parents. On the other hand, they declared that they had good knowledge of IT and access to the internet - mostly broad-band access. Furthermore, the internet was their main source of information and updating. The economic, social and cultural situation of the final semester students compared to the beginners appeared to be better. Part of the statistics gathered by the survey showed that students in the teaching degree courses had a lower socioeconomic status than those in the Law course (PALAZZO, 2015; PALAZZO; GOMES, 2012). In the social hierarchy of curricula, the qualification of educators appears once more with a relatively low level of social prestige, selected by less privileged people (BELTRÃO; MANDARINO, 2014).

Table 1. Numbers of participants by courses and by conditions.

\begin{tabular}{lccc}
\hline Condition & Pedagogy & Mathematics & Total \\
\hline Beginners & 145 & 42 & 187 \\
Finalists & 62 & 13 & 75 \\
Graduates & 155 & 25 & 180 \\
Total & 362 & 80 & 442 \\
\hline
\end{tabular}

Source: Field Survey $(2011 ;$ 2013; 2014). 
Table 2. Predominant characteristics of beginners, finalists and graduates participating in the research, 2011, 2013, 2014.

\begin{tabular}{|c|c|c|c|}
\hline $\begin{array}{l}\text { Predominant } \\
\text { characteristic }\end{array}$ & Beginners & Finalists & Graduates \\
\hline Gender & Female (87.2\%) & Female (89.3\%) & Female (88.2\%) \\
\hline Age & $M=26.0$ years old & $M=29.68$ years old & $M=32.38$ years old \\
\hline Marital State & Single (65.1\%) & Single (46.6\%) & Married (55.6\%) \\
\hline $\begin{array}{l}\text { Skin color } \\
\text { (self-declared) }\end{array}$ & Brown (46.2\%) & Brown (50.7\%) & Brown (51.6\%) \\
\hline Co-residence & $\begin{array}{l}\text { Parents and/or other } \\
\text { relations }(56.2 \%)\end{array}$ & $\begin{array}{l}\text { Partner and/or } \\
\text { children (50.7\%) }\end{array}$ & $\begin{array}{l}\text { Partner and/or } \\
\text { children (63.7\%) }\end{array}$ \\
\hline $\begin{array}{l}\text { Number of } \\
\text { co-residents }\end{array}$ & Three or four (41.4\%) & Three or four (36.0\%) & Three or four (39.0\%) \\
\hline Number of children & None $(67.2 \%)$ & None (49.3\%) & None (49.4\%) \\
\hline $\begin{array}{l}\text { Economic classification } \\
\text { (scale of } A 1 \text { to } E \text { ) }\end{array}$ & B2 (32.8\%) & B2 (36.5\%) & B2 (37.4\%) \\
\hline $\begin{array}{l}\text { Family monthly } \\
\text { income }\end{array}$ & $\begin{array}{l}\text { Up to } 3 \text { minimum } \\
\text { salaries }(46.2 \%)\end{array}$ & $\begin{array}{l}\text { Up to } 3 \text { minimum } \\
\text { salaries }(47.9 \%)\end{array}$ & $\begin{array}{c}\text { From } 3 \text { to } 10 \\
\text { minimum salaries } \\
(56.0 \%)\end{array}$ \\
\hline Economic situation & $\begin{array}{l}\text { No job, costs borne } \\
\text { by the family }(32.6 \%)\end{array}$ & $\begin{array}{c}\text { Work and contribute } \\
\text { to family upkeep } \\
(26.9 \%)\end{array}$ & $\begin{array}{c}\text { Work and contribute } \\
\text { to family upkeep } \\
(58.2 \%)\end{array}$ \\
\hline Work load & $\begin{array}{l}\text { Full-time }-40 \text { hours } \\
\text { a week or more } \\
(35.0 \%)\end{array}$ & $\begin{array}{l}\text { From } 20 \text { to } 40 \text { hours } \\
\text { a week (34.5\%) }\end{array}$ & $\begin{array}{l}\text { Full-time }-40 \text { hours } \\
\text { a week or more } \\
(54.9 \%)\end{array}$ \\
\hline Fathers schooling level & $\begin{array}{c}\text { Primary } \\
\text { education - years } \\
\text { one to four (37.6\%) }\end{array}$ & $\begin{array}{c}\text { Primary } \\
\text { education - years } \\
\text { one to four (38.2\%) }\end{array}$ & $\begin{array}{c}\text { Primary } \\
\text { education - years } \\
\text { one to four (42.9\%) }\end{array}$ \\
\hline Mothers schooling level & $\begin{array}{l}\text { Higher secondary } \\
\text { education (34.4\%) }\end{array}$ & $\begin{array}{c}\text { Primary } \\
\text { education - years } \\
\text { one to four (34.7\%) }\end{array}$ & $\begin{array}{c}\text { Primary } \\
\text { education - years } \\
\text { one to four (39.6\%) }\end{array}$ \\
\hline $\begin{array}{l}\text { Scholarship or } \\
\text { financing for studies }\end{array}$ & None (45.7\%) & None (47.2\%) & None (35.6\%) \\
\hline $\begin{array}{l}\text { Type of school where } \\
\text { higher secondary was } \\
\text { completed }\end{array}$ & Public (86.0\%) & Public (81.3\%) & Public (87.5\%) \\
\hline $\begin{array}{l}\text { Type of higher } \\
\text { secondary education }\end{array}$ & Regular (74.7\%) & Regular (69.4\%) & Regular (61.5\%) \\
\hline $\begin{array}{l}\text { Knowledge of English } \\
\text { (scale of } 1 \text { to } 5 \text { ) }\end{array}$ & $M=1.92$ & $M=1.82$ & $M=1.78$ \\
\hline $\begin{array}{l}\text { Knowledge of Spanish } \\
\text { (scale of } 1 \text { to } 5 \text { ) }\end{array}$ & $M=1.56$ & $M=1.63$ & $M=1.52$ \\
\hline IT skills (scale of 1 to 4 ) & $M=2.97$ & $M=3.17$ & $M=3.14$ \\
\hline
\end{tabular}

Continue 


\begin{tabular}{|c|c|c|c|}
\hline \multicolumn{4}{|l|}{ Continuation } \\
\hline $\begin{array}{l}\text { Computer use } \\
\text { frequency }\end{array}$ & Always (49.7\%) & Always (52.0\%) & Always (58.2\%) \\
\hline Internet access & Yes (95.2\%) & Yes (98.6\%) & Yes (97.8\%) \\
\hline $\begin{array}{l}\text { Use of broad band } \\
\text { service }\end{array}$ & Yes (81.2\%) & Yes (89.0\%) & Yes (95.6\%) \\
\hline Computer use location & Home (89.8\%) & Home $(94.7 \%)$ & Home $(95.6 \%)$ \\
\hline $\begin{array}{l}\text { Purpose of computer } \\
\text { user }\end{array}$ & School work (94.6\%) & School work (96.0\%) & $\begin{array}{c}\text { Communication via } \\
\text { e-mail (85.9\%) }\end{array}$ \\
\hline $\begin{array}{l}\text { Number of } \\
\text { (nonacademic) books } \\
\text { read in the year before }\end{array}$ & $\begin{array}{l}\text { Maximum two } \\
(44.4 \%)\end{array}$ & $\begin{array}{l}\text { Maximum two } \\
(44.4 \%)\end{array}$ & $\begin{array}{c}\text { From three to five } \\
\text { (34.1\%) }\end{array}$ \\
\hline Type of book most read & Fiction (39.2\%) & $\begin{array}{l}\text { Religious books } \\
\qquad(40.0 \%)\end{array}$ & $\begin{array}{l}\text { Religious books } \\
\text { (52.5\%) }\end{array}$ \\
\hline $\begin{array}{l}\text { Frequency of reading } \\
\text { newspapers }\end{array}$ & $\begin{array}{c}\text { Several times a week } \\
(40.8 \%)\end{array}$ & $\begin{array}{c}\text { Several times a week } \\
(40.8 \%)\end{array}$ & $\begin{array}{c}\text { Several times a week } \\
(38.7 \%)\end{array}$ \\
\hline $\begin{array}{l}\text { Topic most read in } \\
\text { newspapers }\end{array}$ & $\begin{array}{c}\text { Culture and/or Art } \\
(39.8 \%)\end{array}$ & $\begin{array}{c}\text { Science. Health } \\
\text { and/or technology } \\
(41.9 \%)\end{array}$ & $\begin{array}{c}\text { Science. Health } \\
\text { and/or technology } \\
\text { (47.1\%) } \\
\text { Culture and/or Art } \\
(47.1 \%)\end{array}$ \\
\hline $\begin{array}{l}\text { Means for keeping up } \\
\text { to date }\end{array}$ & Internet (80.6\%) & Internet (78.4\%) & Internet (92.3\%) \\
\hline $\begin{array}{l}\text { Artistic/cultural } \\
\text { preference }\end{array}$ & Cinema (68.8\%) & Cinema $(80.0 \%)$ & Cinema (81.3\%) \\
\hline
\end{tabular}

Source: Field Survey $(2011 ; 2013 ; 2014)$.

\section{Results}

First it must be stated that for many students, especially those in the Pedagogy course, the teaching course was not their first choice. In some cases, the decision was taken because they had been benefited by the offer of a scholarship of the University for All Program (Prouni). For most of the students in Almeida's (2015) study, obtaining a Prouni scholarship was the only way they could get in to higher education. In other words, it is an alternative for students in the low income bracket:

I intend to finish my Pedagogy course, work in Youth and Adult Education, and then when I can afford it, I intend to study psychology (BPF-42). 
Well, I had the chance of a scholarship. I wanted to take biology, but I am really liking it [Pedagogy] (BPF-55).

Well, actually it was not exactly what I had decided to do, was it? When I sat the entrance exams I had only just finished high school so I did not have a very clear idea of what I wanted. So then I sat the ENEM exams and the Prouni and for the Prouni I had to mark five choices and I ended up choosing Pedagogy [Pedagogy was third choice after Administration and language and literature]. And that was what I got a scholarship for. So because I did not know what I really wanted to do, I ended up in the Pedagogy course (GPF-664).

Because I love the area of exact sciences. Actually at first I had wanted to take engineering but then the scholarship was awarded for Mathematics and I liked that area too (GMF-633).

The perspectives revealed by those graduates seem to confirm the hypothesis of auto-selection in the choice of a higher education course. That is to say, the students anticipate the moment of formal selection and choose courses that are compatible with their socioeconomic and academic characteristics (NOGUEIRA, 2012; NOGUEIRA; ALMEIDA; QUEIROZ, 2011; NOGUEIRA; PEREIRA, 2010; PAUL; SILVA, 1998). The selection occurs on the basis of an a priori estimate of their capacity in comparison with the rest of the candidates and of the intensity of the competition to access each one of the prospective careers (academic auto-selection) in addition to the auto-selection based on their socioeconomic characteristics and gender. In the view of Bueno and Enge (2004), the students, especially those with a socially inferior origin, identify the less sought after courses even if they are not their first choice. Zago (2006, p. 232) goes so far as to question the use of the term "choice" when referring to a higher education course, considering that "for most of them there is no true choice involved at all but, instead, an adaptation, an adjustment to the conditions that the candidates consider to be compatible with their realities and which, accordingly, offer less risk of exclusion."

One aspect that stood out was the dichotomy in the participants' discourse on the social valuing of teaching: at one time, they referred to it as a positive aspect and, at others, as something that was lacking. On the one hand, they recognized the teachers' important role in society, and praised it for that reason, as in the following speech of one of the graduates: "The teacher educates the doctor, he educates the lawyer, he educates them all... understand?” (BPF-2). 
On the other hand, they questioned the social devaluation of the profession frequently associated to poor salaries and precarious working conditions. The very fact of entering on their course had modified some students' views in regards to the profession: "I began to value it more, to acquire a vision that valued the teacher... everyone here knows that teachers are highly undervalued" (BPF-15).

Reciprocal learning is one of the positive aspects mentioned in relation to the course, or as Pimenta and Anastasiou (2005, p, 205) put it, "the "teaching-learning" process in which "the act of teaching is only defined in relation to the act of learning, because apart from the goal, which reveals intentionality, teaching necessarily sets in motion the act of learning”. For the survey participants, teaching is a profession that allows for, and requires continuous learning. Apart from that, there is the emotional gratification, as revealed in the words of the following participants:

I think that what is attractive about it is that you... it's kind of like... you are transmitting to the child and the child is managing to learn (BPF-35).

[...] Apart from the personal satisfaction of collaborating with the students'achievement (FMM-195).

Being a teacher means being an agent of change. Change begins in the classroom and carries on throughout the person's life. The teacher makes a strong contribution to molding mentalities, and that is a highly relevant task. I believe that society is in need of structural changes (FPF-261).

[...] Seeing the results is really something and you get the feeling of having done your duty (FPF-209).

It is rewarding because being a teacher is a mission; it is an opportunity to be part of various individuals who are in the process of formation (FPF-217).

To be able to live in the social reality and know that I can make a difference (FPF-248).

[...] It is rewarding being with the children and being able to pass on to them what you know; it is something magical (GPF-574). 
Because I work with something I really like to do. It is not the kind of job where you wake up and say "Oh God, I've got to go!" No! It's the kind where you say: "Hey... So-and-so will be there. He is so cute. He has already learned to spell his name. He knows to count." Anything they achieve, however small it may seem, I am there, taking part alongside them. I helped them to build. So I think it is just as much an achievement for me as for them (GPF-680).

Because, you know, it is a satisfaction, isn't it?... teaching other children to learn to read, to write. It really gives me tremendous satisfaction (GPF-666).

Nowadays a teacher's function is to, is... I believe we are in a very difficult situation but, even so, it is very gratifying. So from the moment you see a child's smile, you perceive that its developing and learning, you can see in that little face that he can get ahead, become a good citizen, get a good job, because I believe, I do believe that education will be the salvation of our country (GPF-643).

Several participants saw teaching as an assistance-orientated, altruistic, humanitarian project and associated it to their own wish to help their neighbor, to contribute towards improving education in the country and improving Brazilian society, thereby confirming, once more, the literature on this theme (LELIS, 2009; LORTIE, 2002; MELLO, 2003). According to Tardif and Lesard (2009, p. 283), "happiness in work stems from the joy of working with children, youngsters, of helping them; it stems from seeing them grow and progress, change, learn, teach themselves, make discoveries...". In those authors' view, the love that stems from the children is a decisive factor in making choice of the profession and remaining in it, defining the teachers' relation with the work; a fact that is confirmed by the relevant research. The statements below illustrate that vision of giving, priesthood, and vocation, still very much present in society's collective imagery:

It is my way of contributing to society (GMF-510).

It [the profession] is rewarding insofar as you undertake work that will influence the construction of a better, more critical and autonomous society (GPF-521).

It is rewarding to see people being transformed by knowledge that I intermediated (GPF-591). 
From the fact of being aware of the relevance of education and how it collaborates in the life and molding of a citizen (GPF-517).

For the love of education. For the need to improve education in our country more and more (GPF-628).

[I intend] to change the vision, you know, that a lot of people have of education in the public sphere, because many are dissatisfied with education. So then I would like to change their vision a little, wouldn't I? It is not what they think it is (GPF-666).

I think all teachers would like to improve education, wouldn't they? That is what we work towards (GPF-641).

Mello (2003) stated that teaching was seen, above all, as a kind of priesthood, self-giving and humanitarian, for the welfare of others "motivated by subjective reasons such as 'achieve fulfillment as a person, serve ones fellow man, being at peace with oneself" (p. 75). According to Lelis (2009, p. 59), "current collective social imagery is still founded on the rhetoric of mission, of priesthood and vocation, an archetype that strongly impregnates that professional group". Indeed, intrinsic factors such as "working with children, intellectual satisfaction and contributing to society" are important motivations among those that choose to enter the teaching profession in many countries like Australia, Belgium, Canada, France, Holland, Slovakia and the United Kingdom (ORGANIZAÇÃO PARA COOPERAÇÃO E DESENVOLVIMENTO ECONÔMICOS, 2006, p. 70).

Furthermore, some participants, especially those in the Pedagogy course, attributed considerable importance to the question of employability. In their view, the course offers a general qualification that opens up various different labor opportunities:

Because it opens not only professional doors but also doors in terms of civil service entrance exams, because this Pedagogy course opens up a range of opportunities (FPF-236).

It is a course with a broad scope that gives access to various areas of work (FPF-241).

I believe [the profession] will be rewarding because of the quantity of job offers (FPF-216). 
At the time, [I chose the course] because it was one that I could see would benefit me in the future. A broad labor market, a field of work in which I would not only be able to work in the classroom but would have other possible fields I could work in. It was more a question of the labor market (GPF-652).

It is a profession which will never leave us unemployed (GPF-597).

Well, at first it was because of the labor market. My father persuaded me to take it. It was not because I really wanted to, no. I am being sincere [...]. Actually the labor market really is good. When you finish university you don't find yourself unemployed. Today I am teaching on a temporary contract with the Federal District government (GPF-624).

Those data confirm the results that Silva and Speller (2008) obtained. They surveyed graduates in Pedagogy from the Federal University of Mato Grosso (UFMT) and found that one of the motives for which they had originally entered the course was the ease of getting a job after qualifying. According to Miranda (2011, p. 75) teaching is often seen as being "a professional field which has space enough to absorb its qualified professionals; a field with 'open doors' even during times of economic crisis and high unemployment rate, thereby constituting a 'stronghold' of employment".

All the above declarations seem to show that the choice of the course was motivated by practical considerations of people in low-income brackets, anxious to gain employment and achieve their social ascension and, to some extent, for salary considerations. Thus, the data in the literature suggest that the profession is not chosen because of the high level of financial rewards it offers; instead, because of the expectation that it will facilitate entry to the labor and provide relative stability in spite of the steady drops registered in fertility rates and birthrates in Brazil over the last few decades and, consequently, that is, a drop in the numbers of future students. Such points of attraction tend to be less interesting for people that aspire to excellence and high position and more to those who seek alternatives for their professional lives because they feel that other options are almost unattainable, given the limitations inherent to their status, including their financial possibilities. Thus, what can be seen is just the opposite of policy in other countries where incentives are given to attract the most promising youths to a teaching career. Those countries are aware of the outstanding value of basic education to mold 
and qualify their citizens and workers. In other words, they concentrate their attention on the foundations and not on the roofs of their construction.

Negative aspects, in turn, are not only more numerous but they are also cited more frequently. Various earlier studies (BRANDÃO, 2012; ENS; EYNG; GISI, 2009; LEME, 2012; LIMA; SICCA; DAVID, 2012; LUNKES; ROCHA FILHO, 2011; OLIVEIRA et al., 2011; TARTUCE; NUNES; ALMEIDA, 2010; VALLE, 2006) revealed that low salaries and social devaluation are the main motives for dissatisfaction with a teaching career and those were the predominant factors of rejection mentioned by the participants in the present survey.

The question of social devaluation is to some extent related to the low salaries paid to teachers and was also one of the factors with a negative association to the profession and to the teaching degree course itself as can be seen in the excerpt from this participant's statement:

[...] The devaluation of the teacher makes it an unattractive career; and we can see that, can't we? Even in the street it is a course that nobody values much. When you see other professions it seems that everyone in them has a determined value. When you say you are taking a Pedagogy degree, everyone looks down on yоu... (BPF-689).

[The profession] is rewarding if you love it and develop it for that same reason because the poor pay, conditions that are often unfavorable, among other things, contribute towards professional discouragement (FPF-206).

[The profession] is rewarding in some aspects but not in others because, unfortunately, teachers are not highly thought of by society; we work a lot for very low salaries (BPF-249).

One of the undergraduate beginners expressed indignation at the devaluation of the course and the prejudice of other students, narrating what she had overheard in the corridors of the institution: "One day we heard a young man talking to his wife on the phone and he was scandalized because she wanted to take the Pedagogy course: "II that is what you want to do, you'd be better off taking in clothes to wash",", (FPF-29). 
On the other hand, it is sometimes the students themselves who express disdain for the course they are taking as for example the student who declared that he could not afford to take a better course, as if the teaching degree course was something no good: "I am taking the pedagogy course because I like it but also because I am not in a position, as yet, to take a better course, but I think I am doing well because I want to become a teacher and dedicate myself to the study of law" (BPF-13).

The participants were unanimous in citing the rewards, financial or otherwise (like health plans and food vouchers) as negative aspects of the profession. Due to the poor salaries, there is a need to complement income, that is, engage in an additional activity or work longer hours. Working conditions were mentioned in direct relation to the question of remuneration. More specifically mentioned were the large numbers of students in a single class, the accumulation of responsibilities and the great number of hours worked. Barbosa (2011) explains that the teaching profession involves many working hours (distinct from teaching hours which only take place in the classroom), because their work is not limited to the classroom but also involves their private spaces where they carry out tasks such as preparing classes, planning, correcting students' work, elaborating tests, etc.

Teaching malaise, associated to stress caused by overwork or overload and bad working conditions was yet another factor for the rejection of a teaching career. In the research undertaken by Jesus et al. (1992), in the Portuguese context, surveying a sample of 151 teachers in the 2 nd and 3 rd cycles of Basic education (years 5-6 and years 7, 8, 9 respectively) and in secondary education (years $10,11,12)$, the factors that most contributed to teachers' malaise were related to overload and the lack of control over tasks, followed by relations with their peers. The statements taken from the participants reveal that unease:

Continuing in the career wears you down a lot, doesn't it? For someone who starts off very early in life, when age comes creeping in, I am getting older and I just can't take it anymore. That is why the Federal District has so many people pensioned off; everything is coming to a standstill (BPF-130).

A job, if you want earn more you need to have two and it soon becomes very tiring (GPF-50). 
It is an area that pays little and the routine is very tiring and wears you out (GPF-529).

Well, it is very tiring and depending on which municipality you teach in, there is an enormous difference in working conditions (GPF-520).

I learned a lot in the Pedagogy course so I felt a bit frustrated when I entered the labor market, you know? That was because I could see that it is a job that demands a lot from people, a lot. It is not just the work of literacy training and formation or some such thing. You are molding a human being in various ways and so you are constantly called to account and there is a lot of work so we have to really dedicate ourselves. And in the end there is very little recognition considering the work we do, you know? We have work that really wears you down (GPF-664).

The literature confirms the low level of salaries and the profession's social devaluation as factors for the rejection of a teaching career and also as motives for abandoning the profession (BARBOSA, 2011; 2012; BRANDÃO, 2012; BUENO; ENGE, 2004; ENS; EYNG; GISI, 2009; LIMA, 2010; LIMA; SICCA; DAVID, 2012; LUNKES; ROCHA FILHO, 2011; OLIVEIRA et al., 2011; SILVA, 2012; TARTUCE; NUNES; ALMEIDA, 2010; VALLE, 2006). Some cases of teachers abandoning the profession were also identified in the present study:

I have no intention of going back [to work in education] I don't want that at all. I was highly frustrated when I left. I have worked in the area already. So, that is the way it is. I don't want it. I have all the traumas. I don't want it (GPF-649).

At the moment I have a job that is outside of my area of qualification. And the work is better, there is better pay that allows me to take the studies I am engaged in. [I worked in education] yes, for a period of six months and I left it for questions of remuneration (GPF-605).

So then I worked in the area [of Education] for four years. I liked it very much. I was just an assistant but I enjoyed being there in the school, you know? But now I am a trader, I am a trader [...]. I don't believe that pedagogy has much to do with me anymore, no. I don't know whether I would go back to teaching, understand? (GPF-611). 
Another negative aspect of the profession that emerged in one of the groups was the question of violence in school directed as much at teachers as among students:

Nowadays violence among the students and against teachers ends up being a strong discouraging factor, for those who really want to grow and develop in this area; who wants to teach. Because today we can see in the news that a ten year-old child attacked a teacher, you know? I think that kind of thing discourages us a lot (BPF-2).

The graduates surveyed by Gomes and Pereira (2009) also expressed their concern with violence in schools as well as their lack of any training in how to handle it. The absence of parents in the formation of their children and the placing of blame on the school and teachers for the problems in education also came up for discussion when the subject was the factors that repel students from the prospect of embarking on a teaching career "because education is increasingly seen as if it were a cure for all the problems of a salary-earning society and the transformations of the economy" (TARDIF; LESSARD, 2009, p. 282). The participants were also concerned about the responsibility of looking after children:

Nowadays, parents think that the school has to take on their role: educate, correct and everything else. But that is not the case because they do not give us the right to correct the child itself. So I think that much of this violence takes place because the parents do not participate in the education offered in school (BPF-3).

To sum up, the following were identified as factors of attraction associated to teaching:

1. Emotional gratification.

2. Reciprocal learning (teaching-learning).

3. Demand for professionals.

4. Valuation of the profession.

The factors that follow were associated to rejection of the profession and were far more numerous: 
1. Rewards (financial and non-financial), that make it necessary to complement income.

2. Social devaluation.

3. Teaching malaise related to the teacher's stress and health.

4. Violence in schools, both among students and directed at teachers.

5. Divergence between the ideal and the real.

6. Work load, namely classes with too many students, long working hours and accumulated responsibilities.

7. Absence of parents in the formation of their offspring.

\section{Conclusion}

It was categorically shown that most of the factors of attraction associated to teaching were those intrinsic to the profession (emotional gratification, reciprocal learning), while the factors of rejection were mainly extrinsic to it, such as remuneration and reward, social valuation, work load, school violence, malaise and others. Thus. the results corroborate Herzberg's Two Factor Theory (MELLO, 2003; TRIGO-SANTOS, 1996), whereby factors of personal satisfaction are intrinsic to the work (efficiency in performing it, recognition, fulfillment, responsibility, progress in the career), whereas those of dissatisfaction are extrinsic to the work and include salary, social status, policy measures, technical working conditions, interpersonal relations (with colleagues, superiors or subordinate personnel), security, supervision and personal life.

Thus, public policies need to focus on extrinsic sources if they wish to change the status quo. The forms of dissatisfaction are reiterated, nevertheless, effective actions are lacking to meet the challenges; obstacles which appear to be more of a political nature than of an economic-financial one. Obviously, in most cases it is not feasible to offer large linear salary increases. However, the present research shows that there are other ways to increment extrinsic satisfaction. One fear is that even with the gradual ageing of the Brazilian population and the consequent shrinking enrolment figures, the same standards of quality and democratization will be maintained (PALAZZO; GOMES, 2014). Are we going to carry on doing more of the same thing or are we going to break with the present paradigm? 
Compared to other professions that require a university degree, teaching offers lower salaries. Nevertheless, for socially, economically and culturally (in the sense of cultural capital) less well-off candidates, teaching becomes an attractive professional possibility as a way of achieving social and economic ascension. On the other hand, the undergraduate beginners that participated in the survey were fully aware of the negative factors associated to their course right at the beginning of it. Therefore, they must have made a conscious choice and enrolled in spite of them. The data suggest that for a considerable portion of those students teaching is a residual option, "chosen" according to their academic capabilities and, even more so, to their economic capacities. There may still be those with alternative motives such as human relationships, especially with children, while others, inspired by career motivations associated to more competitive and better-rewarded careers seek out other pathways.

How can a country possibly aspire to have quality education if its future educators are those that only chose education because they felt that there were no other openings for them? While other countries are looking to the future and dedicating themselves to research and high quality, democratic education, Brazil persists in its "depositories" for children and young people: in its unequal health service provision that victimizes the majority of the population; in its provincialism; in its "positions of trust" in the sense of making personal indications instead of indications based on merit; in facilitating the issue of diplomas and certificates; in its intellectual and linguistic provincialism; in servile copying instead of original creation. The option continues to be between a fair, competent and democratic country or a country with untreated sewage running in the open air; with the maintenance of a huge electoral mass of poor people to be manipulated by the mechanisms of a clientelism that has just as many archaic as post-modern features. 


\section{Fatores de atratividade e rejeição da carreira do magistério: uma análise a partir de estudantes $e$ egressos de licenciatura}

\section{Resumo}

O presente artigo relata parte dos resultados de uma pesquisa cujo objetivo foi analisar fatores de atratividade e rejeição da carreira docente por parte de uma coorte de alunos ingressantes, concluintes e egressos dos cursos de Licenciatura em Pedagogia e em Matemática de uma instituição privada de ensino superior no Distrito Federal. Para tanto, foram aplicados questionários e conduzidos grupos focais e entrevistas individuais. Os dados foram analisados por meio da análise temática de conteúdo. Os resultados revelam que grande parte dos fatores de atração do magistério foram os intrínsecos à profissão (gratificação emocional, aprendizagem recíproca), enquanto os fatores de rejeição foram majoritariamente extrínsecos a ela, tais como recompensas financeiras, valorização social, carga de trabalho, violências escolares, mal-estar, entre outros. O trabalho conclui que o magistério, apesar de oferecer baixos salários, é uma carreira atrativa aos candidatos menos aquinhoados social, econômica e culturalmente.

Palavras-chaves: Educação superior. Magistério. Escolha profissional. Formação de professores.

\section{Factores de atracción y de rechazo a la carrera del magisterio: un análisis de estudiantes y egresados de programas de licenciatura}

\section{Resumen}

Este artículo reporta parte de los resultados de una investigación que buscó analizar factores de atracción, así como de rechazo a la carrera docente, en relación a una cohorte de estudiantes ingresantes, concluyentes y egresados de cursos de Pedagogía y Matemática de una institución privada de educación superior en el Distrito Federal. Fueron aplicados cuestionarios y realizadas entrevistas individuales, así como grupos focales, utilizándose el análisis de contenido para análisis de los datos. Sus resultados revelan que los más fuertes factores de atracción del magisterio son intrínsecos a la profesión (gratificación emocional, aprendizaje recíproco), mientras los factores de rechazo fueron mayoritariamente extrínsecos, tales como recompensa financiera, valoración social, carga de trabajo, violencia escolares y mal estar. Este trabajo concluye que el magisterio, a pesar de ofrecer bajos salarios, es una carrera atractiva para candidatos menos favorecidos desde los puntos de vista social, económico y cultural.

Palabras clave: Educación superior. Magisterio. Selección de profesiones. Formación de maestros y profesores. 


\section{References}

ALMEIDA, W. M. Os herdeiros e os bolsistas do ProUni na cidade de São Paulo. Educação e Sociedade, v. 36, n. 130, p. 85-100, jan./mar. 2015. doi:10.1590/ES0101-73302015139538

BARBOSA, A. Os salários dos professores brasileiros: implicações para o trabalho docente. Brasília, DF: Líber Livro, 2011.

. Implicações dos baixos salários para o trabalho dos professores brasileiros. Revista Educação e Políticas em Debate, v. 2, n. 2, p. 384-408, jul./dez. 2012.

BECA, C. E. A situação do magistério no Brasil: perfil dos professores da educação básica. In: BALZANO, S. (Org.). O desafio da profissionalização docente no Brasil e na América Latina. Brasília, DF: Unesco, 2007. p. 33-40.

BELTRÃO, K. I.; MANDARINO, M. C. F. Escolha de carreiras em função do nível socioeconômico: Enade 2004 a 2012. Rio de Janeiro: Fundação Cesgranrio, 2014. (Relatório técnico, n. 1/2014).

BRANDÃO, D. F. Você quer ser professor?: um estudo sobre o interesse de licenciandos em Pedagogia pela profissão docente. 2012. 97f. Dissertation (Masters in Social Psichology) - Universidade Federal de Sergipe, Aracaju, 2012.

BUENO, B. O.; ENGE, J. S. Magistério e mercado de trabalho: motivações e dilemas na escolha profissional. Ensaio: Avaliação e Políticas Públicas em Educação, v. 12, n. 44, p. 789-809, jul./ set. 2004.

DINIZ-PEREIRA, J. E. O ovo ou a galinha: a crise da profissão docente e a aparente falta de perspectiva para a educação brasileira. Revista Brasileira de Estudos Pedagógicos, v. 92, n. 230, p. 34-51, jan./abr. 2011.

ENS, R. T.; EYNG, A. M.; GISI, M. L. Políticas de formação de professores e as representações de estudantes de pedagogia e biologia sobre o trabalho do docente. Nuances: estudos sobre Educação, v. 16, n. 17, p. 69-83, jan./dez. 2009. doi:10.14572/nuances.v16i17.321

FERREIRA, A. F.; NASCIMENTO, I.; FONTAINE, A. M. O papel do professor na transmissão de representações acerca de questões vocacionais. Revista Brasileira de Orientação Profissional, v. 10, n. 2, p. 43-56, dez. 2009. 
FRÖHLICH, C. E. A relação entre salários de professores e seleção de candidatos a carreiras de magistério: estimativas para municípios brasileiros entre 2004 e 2010. 2013. 67f. Dissertation (Masters in Economic Development) - Universidade Federal do Paraná, Curitiba, 2013.

GARDUÑO, J. M. G.; SANDOVAL, J. O. Motivación y expectativas para ingresar a la carrera de profesor de educación primaria: un estudio de tres generaciones de estudiantes normalistas mexicanos de primer ingreso. Revista Electrónica de Investigación Educativa, v. 8, n. 2, 2006. Available from: <http://redie.uabc.mx/vol8no2/contenido-garduno.html>. Acess: 2011 Nov. 30.

GATTI, B. A. Atratividade da carreira docente no Brasil: relatório preliminar. São Paulo: Fundação Carlos Chagas, 2009.

GATTI, B. A. (Coord.).; BARRETO, E. S. S. Professores do Brasil: impasses e desafios. Brasília, DF: Unesco, 2009.

GIESTA, N. C. Professores do ensino médio em escolas públicas: o gosto pelo que sabem e fazem na profissão docente. Araraquara: Junqueira \& Marin, 2008.

GOMES, C. A.; PEREIRA, M. M. A formação do professor em face das violências das/nas escolas. Cadernos de Pesquisa, v. 39, n. 136, p. 201-24, jan./abr. 2009. doi:10.1590/S0100-15742009000100010

GOVERNO DE BRASÍLIA. Companhia de Planejamento do Distrito Federal - CODEPLAN. Pesquisa Distrital por Amostra de Domicílios: Distrito Federal - PDAD/DF 2011. Brasília, DF: Codeplan, 2012. Available from: $<$ http://www.codeplan.df.gov.br/component/content/article/261pesquisas-socioeconomicas/257-pdad-2011.html>. Acess: 2012 Dec. 1

JESUS, S. N. et al. Estudo dos factores de mal-estar na profissão docente. Psychologica, n. 8, p. 51-60, 1992.

LELIS, I. A construção social da profissão docente no Brasil: uma rede de histórias. In: TARFIF, M.; LESSARD, C. (Org.). O oficio de professor: história, perspectivas e desafios internacionais. 3. ed. Petrópolis: Vozes, 2009. p. 54-66.

LEME, L. F. Atratividade do magistério para a educação básica: estudo com ingressantes de cursos superiores da Universidade de São Paulo. 2012. 210f. Dissertation (Masters in Education) - Universidade de São Paulo, São Paulo, 2012. 
LIMA, R. C. P.; SICCA, N. A. L.; DAVID, A. Representações sociais de estudantes de pedagogia sobre o trabalho docente em sua trajetória de formação. Educação \& Linguagem, São Paulo, v. 15, n. 25, p. 58-82, jan./jun. 2012. doi:10.15603/2176-1043/el.v15n25p58-82

LIMA, T. Atratividade da carreira docente: um estudo em uma escola da rede pública de ensino de um município da Grande São Paulo. 2010. 131f. Dissertation (Profssional masters in Teaching Maths) - Pontifícia Universidade Católica de São Paulo, São Paulo, 2010.

LORTIE, D. C. Schoolteacher. 2. ed. Chicago: The University of Chicago Press, 2002.

LUNKES, M. J.; ROCHA FILHO, J. B. A baixa procura pela licenciatura em física, com base em depoimentos de estudantes do ensino médio público do oeste catarinense. Ciência e Educação, v. 17, n. 1, p. 21-34, 2011. doi:10.1590/S1516-73132011000100002

MELLO, G. N. Magistério de $1^{\circ}$ grau: da competência técnica ao compromisso político. 13. ed. São Paulo: Cortez, 2003.

MIRANDA, M. H. G. Magistério masculino: (re) despertar tardio da docência. Recife: Ed. Universitária da UFPE, 2011.

NOGUEIRA, C. M. M. Escolha racional ou disposições incorporadas: diferentes referenciais teóricos na análise sociológica do processo de escolha dos estudos superiores. Estudos de Sociologia, v. 2, n. 18, 2012. Available from: <http://www.revista.ufpe.br/revsocio/index. php/revista/article/ view/66>. Acess: 1 Jul. 2013.

NOGUEIRA, C. M. M.; ALMEIDA, F. J.; QUEIROZ, K. A. S. A escolha da carreira docente: complexificando a abordagem sociológica. Revista Vertentes, v. 19, n. 1, 2011. Available from: <http://www.ufsj.edu.br/portal2-repositorio/ File/vertentes/v.\%2019\%20n.\%201/Claudio_Nogueira_e_outros.pdf $>$. Acess: 2013 May 9.

NOGUEIRA, C. M. M.; PEREIRA, F. G. O gosto e as condições de sua realização: a escolha por Pedagogia entre estudantes com perfil social e escolar mais elevado. Educação em Revista, Belo Horizonte, v. 26, n. 3, p. 15-38, dez. 2010. doi:10.1590/S0102-46982010000300002

OLIVEIRA, A. C. et al. Você quer ser professor? E-xacta, v. 4, n. 2, p. 37-42, 2011. 


\section{ORGANIZAÇÃO PARA A COOPERAÇÃO E DESENVOLVIMENTO} ECONÔMICO. Professores são importantes: atraindo, desenvolvendo e retendo professores eficazes. São Paulo: Moderna, 2006.

PALAZZO, J. A escolha do magistério como carreira: por quê (não)?. 2015. 286f. Thesis (Doctor in Educacion) - Universidade Católica de Brasília, Brasília, 2015.

PALAZZO, J.; GOMES, C. A.. Origens sociais dos futuros educadores: a democratização desigual da educação superior. Avaliação, v. 17, n. 3 , p. 877-98, nov. 2012. doi:10.1590/S1414-40772012000300013

. Professores de menos, licenciados demais? Educação Online, n. 15, p. 14-35, jan./abr. 2014.

PAUL, J.-J.; SILVA, N. V. Conhecendo o seu lugar: a auto-seleção na escolha de carreira. Revista Brasileira de Política e Administração da Educação, v. 14, n. 1, p. 115-30, jan./jun. 1998.

PIMENTA, S. G.; ANASTASIOU, L. G. G. Docência no ensino superior. 2. ed. São Paulo: Cortez, 2005.

PIMENTEL, G. S. R.; PALAZZO, J; OLIVEIRA, Z. R. B. B. Os planos de carreira premiam os melhores professores?, Ensaio: Avaliação e Politicas Públicas em Educação, v. 17, n. 63, p. 355-80, abr.jun. 2009. doi:10.1590/S0104-40362009000200009

RABELO, A. "Eu gosto de ser professor e gosto de crianças": a escolha profissional dos homens pela docência na escola primária. Revista Lusófona de Educação, n. 15, p. 163-73, 2010 b.

. Professores homens nas séries iniciais: escolha profissional e mal-estar docente. Educação \& Realidade, v. 35, n. 2, p. 279-298, maio/ago. 2010a.

RAMOS, S. G.; LIMA, E. R. O secundarista e o processo de escolha da profissão. Revista Brasileira de Estudos Pedagógicos, v. 77, n. 185, p. 191-219, jan./abr. 1996.

RUIZ, A. I.; RAMOS, M. N.; HINGEL, M. Escassez de professores no Ensino Médio: propostas estruturais e emergenciais. Brasília, DF: MEC, 2007.

SILVA, A. C. E.; SPELLER, M A. R. Formação e profissão docente. Cuiabá: EdUFMT, 2008. 
SILVA, D. O curso de Licenciatura em Matemática da PUC/SP e a trajetória profissional de seus egressos (2005-2010). 2012. 107f. Dissertation (Masters in Mathematics Education) - Pontifícia Universidade Católica de São Paulo, São Paulo, 2012.

SOARES, D. H. P. A escolha profissional: do jovem ao adulto. 2. ed. São Paulo: Summus, 2002.

SOUZA, L. O. Motivações para a escolha da Licenciatura em Matemática e Pedagogia: um estudo com alunos da PUC/SP e UFMT. 2010. 104f. Dissertation (Masters Profissional em Ensino de Matemática) - Pontifícia Universidade Católica de São Paulo, São Paulo, 2010.

TARDIF, M.; LESSARD, C. O trabalho docente: elementos para uma teoria da docência como profissão de interações humanas. 5. ed. Petrópolis: Vozes, 2009.

TARTUCE, G. L. B. P.; NUNES, M. M. R.; ALMEIDA, P. C. A. Alunos do ensino médio e atratividade da carreira docente no Brasil. Cadernos de Pesquisa, v. 40, n. 140, p. 445-77, maio/ago. 2010. doi:10.1590/S0100-15742010000200008

TRIGO-SANTOS, F. Atitudes e crenças dos professores do ensino secundário: satisfação, descontentamento e desgaste profissional. Lisboa: Instituto de Inovação Educacional, 1996.

VALLE, I. R. Carreira do magistério: uma escolha profissional deliberada? Revista Brasileira de Estudos Pedagógicos, v. 87, n. 216, p. 178-187, maio/ago. 2006.

ZAGO, N. Do acesso à permanência no ensino superior: percursos de estudantes universitários de camadas populares. Revista Brasileira de Educação, v. 11, n. 32, p. 226-37, maio/ago. 2006. doi:10.1590/S1413-24782006000200003

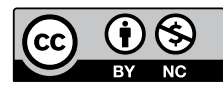

\section{Informações dos autores:}

Candido Alberto Gomes: Doutor em Educação pela Universidade da Califórnia, Los Angeles. Professor na Universidade Católica de Brasília. Contato: clgomes@terra.com.br

Janete Palazzo: Doutora em Educação pela Universidade Católica de Brasília. Contato: janjanpalazzo@yahoo.com.br 